\title{
A RUPTURA DOS DIREITOS HUMANOS NA FILOSOFIA POLÍTICA DE HANNAH ARENDT
}

\author{
Fausto Brito* \\ brito.fausto@gmail.com
}

RESUMO $O$ objetivo deste artigo é a análise das críticas de Hannah Arendt à concepção dos direitos humanos, introduzida pelo pensamento dos filósofos contratualistas e efetivada, politicamente, pelas revoluções americanas e francesas no final do século XVIII. Contudo, este objetivo não seria plenamente alcançado sem a avaliação da proposta de Arendt para a superação de suas próprias críticas: a reconstrução dos direitos humanos através do reconhecimento que cada indivíduo tem direito a ter direitos, independente das fronteiras do Estado-nação. Arendt vai buscar na moral universalista e cosmopolita kantiana o conceito de humanidade e dá a ele as dimensões ontológicas e políticas necessárias para se construir um espaço público internacional, onde o direito a ter direito seja decorrente do mero pertencimento à humanidade, não se dissolvendo nos limites de cada Estadonação.

Palavras-chave Hannah Arendt, filósofos contratualistas, critica à concepção dos direitos humanos, direito a ter direitos

ABSTRACT The purpose of this article is the analysis of the criticisms of Hannah Arendt's conception of human rights, introduced by the thought of the contractual philosophers and made effective, politically, by American and French revolutions in the late eighteenth century. However, this aim would not be fully achieved without the review of Arendt's proposal to overcome her

* Professor da Faculdade de Economia da UFMG. Artigo recebido em 30/1/2012 e aprovado em 2/6/2012.

KRITERION, Belo Horizonte, nº 127, Jun./2013, p. 177-196 
own criticisms: the reconstruction of human rights by recognizing that every individual has the right to have rights, regardless of borders of the NationState. Arendt tries to discover in the universal and cosmopolitan moral of Kant the concept of humanity and gives him the ontological and political dimensions needed to build an international public space where the right to have rights is due to the mere belonging to the humanity, not dissolving itself in the limits of each Nation-State.

Keywords Hannah Arendt, contractual philosophers, criticism to the conception of human rights, the right to have rights

O tema "Direitos humanos" tem acompanhado a filosofia política moderna desde Thomas Hobbes, assim como a história contemporânea desde as Revoluções Americana e Francesa. A Declaração da Independência dos Estados Unidos, de 1776, e a Declaração dos Direitos do Homem e do Cidadão, de 1789, enunciaram, efetivamente, a universalidade dos direitos humanos, os quais fizeram do homem não só a sua fonte, mas também o portador de direitos inalienáveis. Nessa perspectiva, a política moderna adquiriu um novo fundamento no final do século XVIII: o absoluto não era mais um deus ou um rei, mas o indivíduo, com seus direitos fundamentais intrínsecos à natureza humana.

O itinerário histórico dos direitos humanos encontrou muitos obstáculos desde os seus primeiros anos, logo após as duas mais importantes revoluções burguesas. A contribuição de Hannah Arendt para sua análise foi decisiva, na medida em que elaborou um caminho teórico que permitiu compreender seu verdadeiro significado para a filosofia e para a política.

A chave conceitual para essa compreensão é o que Arendt considera como a ruptura dos direitos humanos. ${ }^{1}$ Em verdade, esta é a ponta mais insinuante do iceberg. A ruptura não foi só a do direito, mas também do fluxo da história e a da tradição do pensamento ocidental. Ela começa a configurar-se no período do imperialismo, principalmente nas três décadas entre 1884 e 1914, quando se expandem as ideologias raciais, que se transformaram, muitas vezes, em políticas de Estado. 
A cristalização histórica da ruptura dos direitos humanos ocorre de um modo contundente entre as duas Grandes Guerras, com a barbárie totalitária do nazismo e do stalinismo. Essa tragédia sem precedentes cria uma massa de homens supérfluos, excluídos socialmente, despidos de qualquer direito, postos em sua cruel naturalidade nos campos de concentração e de trabalho.

Entre a expansão das ideologias raciais e o momento do totalitarismo, a ruptura começa a torna-se evidente na cena política com o aparecimento dos "displaced persons", compreendidos como os apátridas, e as minorias, que não tinham mais aqueles direitos consagrados como inalienáveis. De acordo com Arendt, a filosofia contratualista e as Declarações de 1776 e de 1789, tiveram a virtude de fazer do homem a fonte destes direitos e de torná-los inalienáveis. Entretanto, os displaced persons, homens sem lugar na sociedade e na política, afrontavam a fundamentação metafísica desses direitos ancorada na natureza humana. ${ }^{2}$

Essa é a primeira crítica de Arendt aos direitos humanos. Justificados como inerentes à pessoa humana, eles desvelam uma paradoxal dimensão prépolítica. Os homens não são iguais nem livres por natureza. Se assim fossem, os apátridas e as minorias não teriam perdidos seus direitos. Perderam-nos justamente porque ficaram reduzidos à mera natureza humana, sem inserção no mundo - em especial, no mundo da política. A igualdade e a liberdade humanas só têm possibilidade de acontecer no espaço público, ou da política, construído pelos próprios homens e fundado no princípio da isonomia. É na política, e não na natureza humana, que os direitos humanos se fundamentam.

A segunda crítica de Arendt refere-se à Revolução Americana e à Revolução Francesa, quando os direitos humanos, efetivados politicamente, foram subordinados à soberania nacional e identificados com os direitos dos nacionais.

As duas primeiras críticas de Arendt reconsideram não só as declarações de direitos das duas revoluções, mas também o pensamento contratualista dos séculos XVII eXVIII. Muitos de seus conceitos espalharam-se pelas Revoluções Americana e Francesa e aparecem em suas respectivas declarações. Pode-se encontrar em Thomas Hobbes (1588-1679), John Locke (1632-1704) e JeanJacques Rousseau (1712-1779) a compreensão dos direitos humanos como intrínsecos à natureza humana e com seus limites impostos pela constituição da sociedade política.

Arendt considera, também, que essas revoluções inauguraram a sociedade política contemporânea, distinguindo os direitos dos homens dos 
direitos civis. $\mathrm{O}$ essencial dessa distinção está na diferença entre liberdade e liberdade negativa. A última se institucionaliza nos direitos civis, consagrados constitucionalmente, que estabelecem limites à ação do Estado. Trata-se de uma liberdade negativa, pois não se constitui necessariamente na inserção essencial do homem no mundo da política, que somente acontece por meio do acesso à participação na gestão do espaço público comum. Neste espaço, construído pelo próprio homem, é que a liberdade se realiza em sua dimensão positiva; ou seja, no exercício do direito fundamental de participar da política.

A análise das críticas de Arendt, introduzidas a partir de uma reflexão sobre o pensamento contratualista no que se refere à liberdade e aos direitos humanos, constitui-se no objetivo fundamental deste artigo. Contudo, ele ficaria incompleto sem a avaliação da proposta de Hannah Arendt para a superação das suas próprias críticas, isto é, a reconstrução dos direitos humanos mediante o reconhecimento do direito que cada indivíduo tem a ter direitos, independente das fronteiras do Estado-nação.

$\mathrm{O}$ direito a ter direitos, segundo Arendt, não se fundamenta na natureza humana, conforme os contratualistas ou as declarações das Revoluções Americana e Francesa, mas sim na sua concepção de humanidade. Ela vai buscar na moral universalista e cosmopolita kantiana o conceito de humanidade e atribui a ele a dimensão política necessária para se compreender o espaço público internacional, em que o direito a ter direito decorre do mero pertencimento a ela, não se dissolvendo nos limites de cada nação. Essa concepção de um espaço político internacional, em que a liberdade essencial dos indivíduos realiza-se independente da sua nacionalidade, não é nada trivial, considerando as relações internacionais hoje vigentes. Porém, a sugestão de Arendt é instigante e abre-se para um tema decisivo: como conciliar uma proposta de tutela internacional dos direitos humanos com a soberania de cada país, considerando que as democracias liberais contemporâneas, com seus resíduos totalitários, cada vez mais reduzem os direitos dos homens aos direitos dos cidadãos em seus respectivos países. ${ }^{3}$

\section{A Fundamentação metafísica dos direitos humanos e a construção da sociedade política}

As críticas de Arendt à justificativa naturalista dos direitos humanos, a suas relações com a soberania nacional e à ambiguidade entre os direitos dos homens e o direito dos cidadãos já podiam ser observadas nos próprios 
filósofos contratualistas, antes das declarações revolucionárias do final do século XVIII.

Em Hobbes, como nos demais contratualistas, o ponto de partida para se compreender os direitos do homem é o conceito de liberdade no estado de natureza. Ele considera que há uma igualdade natural entre os homens, não na posse de bens, mas nas faculdades do corpo e do espírito, o que atribui a cada um a mesma capacidade de aspirar a qualquer benefício a que o outro também possa aspirar. A igualdade nas aspirações é a razão principal dos conflitos entre os homens no estado de natureza. Dela surgem a competição e o confronto sem limites, e as relações sociais são corrompidas. Emerge, como diz Hobbes, "o que é pior do que tudo, um medo contínuo e o perigo de morte violenta. E a vida do homem é solitária, miserável, sórdida, brutal e curta". ${ }^{4}$

Neste contexto de conflito e instabilidade social no estado de natureza, em que o medo e o perigo da morte acompanham o indivíduo, a liberdade é um direito natural, a Jus Naturale. ${ }^{5}$ Todavia, no seu próprio exercício, buscando a conservação da vida, os homens mergulhados na competição geram obstáculos à própria conservação da vida, suscitando não somente o medo da morte, mas também o desejo de uma vida confortável e a vontade consegui-la por meio do trabalho. ${ }^{6}$

A igualdade e a liberdade, regras gerais estabelecidas pela razão para a manutenção da própria vida, são insuficientes para garantir a paz se não for instituído um poder superior, por meio de um contrato social, que garanta pelo temor o respeito a elas. ${ }^{7}$ Contratar para obter a paz, segundo o pensamento hobbesiano, é um direito do indivíduo, fundado nas leis da natureza voltadas para a conservação da vida. ${ }^{8}$

O contrato social é uma transferência mútua de direitos e depende da vontade de ambas as partes, já que se trata de um ato voluntário e, portanto, derivado da liberdade natural..$^{9}$ Mais do que um acordo ou um consentimento, o contrato é a unidade de todos os homens em uma só pessoa ou assembleia. É como se todos dissessem: "Autorizo e transfiro o meu direito de me governar a mim mesmo a este homem, ou a esta assembleia de homens, com a condição de transferir para ele o teu direito, autorizando de uma maneira semelhante todas as suas ações. Feito isso a multidão, assim unida numa só pessoa, chama-se

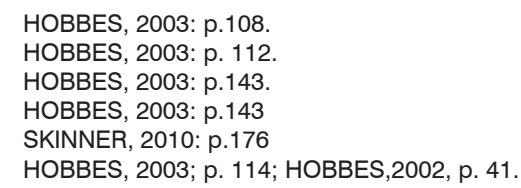


"República", em latim Civitas. É esta a geração daquele Leviatã, ou, antes, para falar em termos mais reverentes, daquele Deus mortal, ao qual devemos, abaixo do Deus imortal, a nossa paz e defesa". ${ }^{10}$

$\mathrm{Na}$ República, a liberdade estaria, apenas, naquelas ações que não são reguladas pelo soberano. Enquanto tal, situa-se unicamente na esfera privada, onde impera o "silêncio das leis". ${ }^{11}$ A liberdade não é, então, um direito individual. $\mathrm{O}$ poder absoluto concedido pelos homens à República, de fato, significou a submissão à sua vontade, concedendo-lhe um domínio absoluto, pois ou se submetem às leis ou decretos ou serão relegados ao estado de guerra em que viviam anteriormente ao contrato. ${ }^{12}$

O poder do Estado absolutista só encontra limite no direito inalienável do homem de dispor os meios necessários à preservação de sua vida. Esta é a liberdade civil para Hobbes. Homem algum, segundo a própria lei da natureza, pode ser impedido de utilizar todos os meios necessários à conservação de sua vida. ${ }^{13}$ Desse modo, a obrigação dos súditos, inerente às leis do contrato, só tem legitimidade enquanto o soberano tem o poder de garantir o próprio objetivo do contrato - isto é, proteger a vida dos súditos. ${ }^{14}$ Caso contrário, os homens podem e devem resistir ao poder do Estado.

O direito do homem em Hobbes, que prevalece tanto no estado de natureza quanto na sociedade política, é somente o direito de preservar a própria vida. Essa é a única dimensão da liberdade civil, pois o direito de resistência é uma decorrência do mesmo direito de preservar a vida.

A influência do pensamento de Hobbes sobre os eventos revolucionários na América e na França, certamente, é desconsiderável. Contudo, sua importância para o pensamento de Locke, em particular, e para a formação da ideologia burguesa, em geral, é de grande relevância. ${ }^{15}$ De outro lado, é reconhecida a influência de Locke sobre a Declaração de Independência dos Estados Unidos e sobre a Declaração dos Direitos Humanos e do Cidadão da Revolução Francesa. ${ }^{16}$

A análise de Locke sobre a liberdade inicia-se, também, com o estado de natureza, governado pela lei natural, que assegura a todos os homens os direitos à vida, à saúde, à liberdade e à posse. ${ }^{17} \mathrm{~A}$ lei natural coloca nas mãos de 
cada homem o poder para a sua execução e, portanto, o poder de preservação de seus direitos e dos direitos dos outros homens. Assegura, então, a cada um o poder de punir quem a transgride. ${ }^{18}$

Quando uma pessoa tenta subordinar a outra ao seu poder absoluto, é racional, segundo a lei natural, que ela seja considerada como um inimigo, pois pretende usurpar a liberdade necessária para garantir o direito à vida. ${ }^{19}$ $\mathrm{O}$ estado de guerra é uma consequência extrema do estado de natureza. Para evitá-lo é que os homens encontram a razão primordial para abandoná-lo e para construir uma sociedade política. Nela, diz Locke, a "liberdade dos homens sob um governo consiste em viver segundo uma regra permanente comum a todos nessa sociedade e elaborada pelo Poder Legislativo nela erigido: liberdade de seguir a minha própria vontade em tudo que escapa à prescrição da regra e de não estar sujeito à vontade inconstante, incerta, desconhecida $\mathrm{e}$ arbitrária de outro homem". ${ }^{20}$

$\mathrm{O}$ direito à liberdade $\mathrm{e}$ o direito à propriedade aparecem juntos em Locke e fundamentam a sua filosofia do contrato social. ${ }^{21}$ Os homens não fariam uma adesão voluntária ao contrato se não fosse para viverem sob leis estabelecidas pelo consentimento. Não aceitariam, assim, a tirania, que seria o exercício do poder pelo governante, além do direito, em proveito da sua própria vontade. $\mathrm{O}$ direito de resistência à tirania fica assegurado, pois quando "os tiranos violarem ou destruírem a propriedade do povo ou reduzi-lo à escravidão sob um poder arbitrário, colocar-se-ão em estado de guerra contra o povo, que fica, a partir de então, desobrigado de toda a obediência". ${ }^{22}$

A importância decisiva de Rousseau sobre a declaração francesa dos direitos humanos é incontestável. ${ }^{23}$ Seu texto, além da influência de Locke e da marca dos fisiocratas, contém um poderoso legiscentrismo, fruto da vontade geral, de feitura incontestavelmente rousseauniana. ${ }^{24}$

Rousseau utiliza o conceito de estado da natureza, um postulado hipotético, como em Hobbes e Locke, supondo que os homens chegam a uma situação social em que a liberdade natural coloca em risco a conservação de suas próprias vidas. Na luta pela sobrevivência, os homens rompem o estado de natureza e podem tornar-se um mero agregado em que a base das 
relações sociais seja a submissão assentada na relação senhor-escravo. Faz-se necessário, então, uma primeira convenção, $o$ ato de fundação para estabelecer uma nova sociedade política. ${ }^{25}$

$\mathrm{O}$ ato de fundação do pacto social é uma ação civil que pressupõe uma deliberação pública, um acordo sobre o interesse comum. Não se trata de fundar uma agregação social e política qualquer, mas uma associação em que há um interesse comum: a construção de um corpo político e moral. Como o contrato é um ato voluntário, o povo, sujeito soberano, deve ter regras que definam a instituição do sufrágio. Pelo menos, neste caso, deve haver consenso. ${ }^{26}$

A existência de opositores ao contrato não o invalida; impossibilita apenas que estes se incluam nele. Por isso, considerados estrangeiros entre os cidadãos. Em outras palavras, quando se institui o Estado com base no pacto social, a residência no território implica na submissão à soberania. ${ }^{27}$

O contrato social possibilita resolver um problema fundamental: como estabelecer a concordância entre a obediência e a liberdade ou entre o súdito e o cidadão? Para que isso aconteça, à liberdade, própria do Estado natural, em que cada indivíduo depende exclusivamente de suas próprias forças, sucedemse a liberdade civil e o direito de propriedade. Segundo Rousseau, a adesão ao contrato significa que "cada um de nós põe em comum sua pessoa e todo o seu poder sob a suprema direção da vontade geral; e recebemos, coletivamente, cada membro como parte indivisivel do todo" (grifo de Rousseau). Cria-se uma associação, um corpo moral e coletivo do qual participam todos os que votam na Assembleia, constituindo uma unidade, um eu comum. Essa pessoa pública, antes considerada como Cidade, agora se denomina "República", ou "Corpo político", que seus membros chamam de "Estado", expressão da vontade geral. Os associados, "recebem coletivamente o nome de povo e se chamam, em particular, cidadãos, enquanto participantes da autoridade soberana, e súditos enquanto submetidos às leis do Estado". ${ }^{28}$

A liberdade natural, acompanhada pelo direito ilimitado, é substituída pela liberdade civil, limitada pela vontade geral. E, do mesmo modo, a posse de seus bens, garantidos pela força no estado de natureza, é substituída pela propriedade garantida pela lei. ${ }^{29}$ A liberdade civil tem seu limite. Quando o príncipe julga que é útil ao Estado que o indivíduo morra, deve morrer, "pois foi somente graças a essa condição que até então viveu em segurança e que a 
sua vida já não é apenas uma dádiva da natureza, mas um dom condicional do Estado". ${ }^{30}$ Do mesmo modo, se o cidadão rompe com o pacto social deve ser exilado ou punido, até mesmo pela morte, como inimigo público.

Por meio do contrato social, o corpo político passa a ter vida, mas é somente pela legislação que ele adquire vontade e movimento. As leis e as convenções estabelecem os direitos e os deveres que visam à justiça. ${ }^{31} \mathrm{~A}$ República seria, então, "todo o Estado regido por leis, qualquer que seja a sua forma de administração, porque só então o interesse público governa e a coisa pública significa algo". Todo governo legítimo, isto é, governado pela vontade geral - que é a lei - é republicano. ${ }^{32}$

$\mathrm{Na}$ construção filosófica dos contratualista, a liberdade é um conceito fundamental, pois a sua negação é condição necessária, dentro do direito natural, para se contratar, obter a paz e garantir o direito fundamental à vida. Como a adesão ao contrato é voluntária, depende, portanto, da vontade individual. $\mathrm{O}$ ato de fundação ainda pressupõe a liberdade natural, que cessa depois do contrato. Na sociedade política que emerge, os direitos naturais são transferidos ao poder absoluto do Estado, como em Hobbes, e a liberdade deixa de ser individual e passa a ser do corpo político. A liberdade só se mantém no espaço privado que não está subordinado ao poder da lei. Ou seja, a liberdade se mantém somente na esfera da satisfação das necessidades dos indivíduos.

Em Locke, os direitos individuais são colocados na mão do público e se subordinam às leis consentidas, elaboradas pelo Poder Legislativo. A liberdade natural, como em Hobbes, só prevalece nos espaços sociais onde a lei não alcança. Mesmo sob o silêncio da lei, a vontade do indivíduo deve orientar-se pela razão prudencial. Contudo, há uma novidade essencial que merece ser sublinhada: o liberalismo de Locke caracteriza-se não só pela obediência à lei consentida, que transforma a liberdade natural em liberdade civil e a posse em propriedade, mas, também, pelos limites postos à tirania. $\mathrm{O}$ direito de resistir à tirania define limites à ação do Estado quando estiver em risco a liberdade essencial, definida pela lei consentida, necessária à preservação da vida e da propriedade.

A liberdade natural em Rousseau, ilimitada como nos outros contratualistas, depois da fundação da sociedade política, subordina-se à vontade geral, fruto do consenso. O indivíduo põe em comum sua pessoa, sua liberdade e 
seus direitos, sob a direção da vontade geral, reconhecendo-se como parte indivisível do todo. O pressuposto é que o contrato, a realização da vontade geral, ocorre por meio de uma deliberação pública sobre o interesse comum.

Esta síntese dos interesses do indivíduo e do Estado, mediatizada pela vontade geral, torna-se possível porque os indivíduos passam a ser, simultaneamente, súditos e cidadãos, ou seja, parte do poder soberano que elabora as leis, mas, ao mesmo tempo, plenamente subordinados às leis do Estado. Os direitos dos indivíduos em Rousseau estão postos em comum, sob a direção da vontade geral. São menos direitos dos indivíduos e mais direitos de uma pessoa moral, o homem novo da sociedade política, cuja vida não é mais uma dádiva de deus, mas um dom condicional do Estado governado pela vontade geral expressa nas leis.

Em Rousseau está mais evidente, mas encontra-se também em Hobbes e Locke, a relação entre soberania e território. A não adesão ao contrato implica que o indivíduo seja considerado um "estrangeiro". A criação de uma sociedade política, ou do Estado, não se diferencia da criação de uma sociedade civil de cidadãos e súditos que aderiram ao contrato e que residem em determinado território. O conceito de povo, tão usado em Rousseau, delimita os que participam do poder soberano e dele podem ser excluídos se acaso não mais se subordinarem às leis do contrato.

\section{A Crítica de Hannah Arendt: a emergência dos apátridas e a ruptura dos direitos humanos}

As críticas de Hannah Arendt aos direitos humanos, conforme eles se apresentam nas declarações de 1776 e 1789, podem ser estendidas aos contratualistas nos quais os atos revolucionários, em boa parte, se inspiraram. A fundamentação no direito natural, a identificação dos direitos dos cidadãos como o direito daqueles subordinados às leis dos Estados-nacionais e, consequentemente, a transformação dos direitos humanos em direitos civis são próprias da filosofia dos contratualistas. ${ }^{33}$

Segundo Arendt, o confronto com a tradição dos direitos humanos tornase evidente com a desintegração de diversos Estados-nação europeus entre as duas Grandes Guerras e no período imediatamente após a Segunda, quando do grande deslocamento espacial da população emergiram dois grandes atores fundamentais: os apátridas e as minorias. 
As minorias eram apenas parcialmente povos sem Estado, pois pertenciam a uma comunidade política, ainda que fosse necessária a proteção de entidades externas, como a Liga das Nações, para lhes assegurar algumas garantias especiais. Proteção tênue, sem dúvidas, pois dependia da anuência do Estadonação ao qual essas minorias estavam vinculadas. Alguns de seus direitos, como a preservação da sua cultura e a do seu próprio idioma, estavam em permanente ameaça. ${ }^{34}$

Deoutro lado, os apátridas eram verdadeiramentepessoas sem Estado, como os armênios, os romenos, os húngaros, os russos e os alemães, nos respectivos países para os quais se deslocaram. De fato, eles foram desnacionalizados pelos governos vitoriosos e expulsos de seus respectivos países. Eles perderam sua nacionalidade no lugar de origem, e consequentemente a proteção do seu Estado natal, e não readquiriram, nem uma nem outra, no lugar de destino. ${ }^{35}$

Sem pertencerem, de fato, a um Estado nacional, os apátridas não tinham um lugar próprio, não faziam parte de um corpo político que lhes garantissem a proteção da lei. Eram para o Estado nas nações de destino pessoas supérfluas sem direitos reconhecidos. Os "displaced persons", como eram chamados os apátridas, se constituíam em uma exceção política: desnacionalizados no Estado de origem, não tinham a cidadania reconhecida no Estado de destino; eram pessoas sem lugar no mundo social e político. ${ }^{36}$

Arendt destaca ainda um terceiro tipo de população que se deslocava entre países, distinto dos dois anteriores e que já começava a adquirir importância: os imigrantes econômicos. Ela se refere particularmente ao caso da França, que, devido a suas condições demográficas, precisava se nutrir de trabalhadores estrangeiros para seu mercado de trabalho. Apesar de necessários, nem por isso deixavam de recair sobre eles pesadas medidas restritivas, como a deportação em tempo de crise e desemprego. ${ }^{37}$

O interesse maior de Arendt, no entanto, são os apátridas que haviam perdido "aqueles direitos que até então eram tidos e até definidos como inalienáveis, ou seja, os Direitos do Homem...". ${ }^{38}$ A emergência histórica desses expulsos da clássica trindade Estado-Povo-Território trazia à tona a associação entre direitos humanos e soberania nacional. Para os apátridas, em particular, a não inclusão em uma comunidade política - portanto, a exclusão dos direitos de cidadão no lugar de destino - significava a perda dos direitos 
humanos consagrados na tradição ocidental pelos contratualistas e pelas declarações americanas e francesas. ${ }^{39}$

Essas declarações dos Direitos do Homem, proclamadas no fim do século XVIII, são um marco na história. Elas serviram de fundamento para o Estado moderno, cuja legitimação deixava de se fundamentar em motivos religiosos ou em hierarquias sociais que dividiam a população em estamentos definidos pelos seus privilégios sociais. Nas declarações, o homem tem, por sua natureza, direitos inalienáveis, que não dependem de suas posições na sociedade e na política, mas, pelo contrário, precedem a elas; são direitos naturais e, portanto, intrínsecos à natureza humana, e o contrato social deve garanti-los. ${ }^{40}$

A Declaração de Independência dos Estados Unidos, de 1776, consagra que todos os homens são iguais e dotados de certos direitos inalienáveis, entre eles a vida, a liberdade e a busca da felicidade, e que os governos são instituídos, com o consentimento dos governados, para assegurar esses direitos. Se o governo não obedecer a este fim, é direito do povo revoltarse contra essa forma de governo e instituir uma nova. Inspirada em Locke, justifica-se a revolta dos norte-americanos contra o sistema colonial imposto pela Grã-Bretanha e impróprio para um povo livre. ${ }^{41}$

A Declaração dos Direitos do Homem e do Cidadão, de 1789, considera que a ignorância, a negligência e o menosprezo dos direitos dos homens são as únicas causas dos males públicos e da corrupção governamental. ${ }^{42}$ Suas grandes novidades estão contidas nos três primeiros artigos da Declaração. $\mathrm{O}$ primeiro reconhece que os homens nascem e permanecem livres e iguais em direitos sagrados e inalienáveis. O segundo enuncia que o objetivo do contrato social, ou da associação política, é a "conservação dos direitos naturais e imprescritíveis do homem, tais como a liberdade, a propriedade, a segurança e a resistência à opressão". O terceiro artigo afirma que o princípio da soberania reside na nação, e não em ordens ou estamentos. ${ }^{43}$

Sobre a soberania, a Declaração francesa é mais específica, com grande influência de Rousseau e, certamente, como resultado de sua característica fundamental: trata-se não de uma guerra de independência, como nas colônias americanas, mas da destruição revolucionária do antigo regime, ancorado nas relações feudais que garantiam o absolutismo monárquico. Deixava-se para trás, na história, um corpo político cindido pelos estamentos, cuja unidade só 
se realizava pela imposição da autoridade monárquica e introduzia-se na cena política a unidade da nação construída pelo poder soberano do povo.

Arendt reconhece a novidade histórica dos direitos humanos proclamados pelas declarações americana e francesa, porém critica sua fundamentação no direito natural segundo a tradição dos contratualistas. Os homens não são iguais por natureza. O que torna os homens iguais é o artifício da política construído pelos homens para que o mundo comum seja compartilhado. No pensamento arendtiano, os direitos humanos só podem ser compreendidos no plano da política. Eles são definidos em função da pluralidade humana, e não em função de um homem na sua singularidade natural. ${ }^{44}$

A crítica de Arendt aos direitos humanos, na concepção dos contratualistas e nas afirmações das declarações revolucionárias, não se reduz somente à sua fundamentação na "natureza humana", mas se estende a sua relação com a soberania nacional. O ser humano, na sua individualidade abstrata, só assumia seu rosto de cidadão por intermédio do povo ao qual pertencia. Os direitos humanos, portanto, só se definiam com a emancipação de um povo ou, em outras palavras, com a constituição de um Estado nacional soberano. ${ }^{45}$

As revoluções - em particular, a francesa - subordinaram os direitos do homem à soberania nacional. O resultado objetivo é que eles passaram a ser considerados e protegidos como direitos nacionais. Esta, para Arendt, é a tragédia do Estado-nação moderno, que somente reconhece como cidadãos aqueles que pertencem à comunidade nacional, os únicos que podem usufruir plenamente dos direitos civis e políticos. ${ }^{46} \mathrm{O}$ princípio da nacionalidade se transforma no vínculo entre o indivíduo e o Estado e é condição necessária para ser membro da comunidade política. ${ }^{47}$

A grande calamidade é que a liberdade de participar de uma comunidade política não pode realizar-se em um contexto no qual os Estados nacionais vinculam os direitos humanos, em geral, e os direitos políticos, em particular, somente aos cidadãos nacionais. Este é o grande paradoxo dos direitos humanos, pois se supunha que, intrínsecos à natureza humana, como professavam os contratualistas e as declarações revolucionários, fossem independentes da nacionalidade. ${ }^{48}$

Quando surgem, então, na cena histórica aqueles como os apátridas, que não participam de nenhuma comunidade política, o conceito de direitos 
humanos perde sua eficácia. Totalmente despidos de seus direitos humanos fundamentais - sem que o mundo visse nada de sagrado nessa abstrata nudez de ser unicamente humano - os apátridas eram uma afronta às conquistas das declarações americana e Francesa. ${ }^{49}$

A visão dos direitos humanos exclusivos dos nacionais tende a uma concepção do Estado-nação que pressupõe uma homogeneidade do seu povo. Schmitt afirma que, segundo o princípio da nacionalidade, o Estado democrático encontra seus fundamentos na homogeneidade nacional. ${ }^{50}$ Habermas alerta para o problema dessa formulação, pois a homogeneidade nacional tende a se confundir com a identidade étnica de um povo, considerada um dado pré-político ${ }^{51}$, ao contrário da perspectiva republicana, em que o povo se constitui voluntariamente no contrato social, sem precondição étnica, mas na sua inteira diversidade..$^{52}$

A concepção de homogeneidade étnica como base do Estado-nação consagra a ruptura dos direitos humanos, que passa a ser um privilégio dos nacionais e, mais radicalmente, dos nacionais de etnias semelhantes. Tratase, historicamente, da antessala de um regime totalitário quando se rompe radicalmente com toda a tradição ocidental e o homem deixa de ser a fonte do direito. Uma sociedade de campos de concentração e de trabalho é precedida pela geração de enormes contingentes de homens supérfluos, social e politicamente. ${ }^{53}$

Apesar das críticas, Hannah Arendt compreende as revoluções Americana e Francesa como um novo começo na história, e o enredo dessa novidade é o aparecimento da liberdade. ${ }^{54}$ Nas democracias liberais contemporâneas, a liberdade está associada aos chamados "direitos civis". Estes são o resultado dos três grandes direitos fundamentais, originários das revoluções do final do século XVIII, que já se encontravam nos contratualistas, em especial em Locke e Rousseau: o direito à vida, o direito à liberdade e o direito à propriedade, considerados inalienáveis e em relação aos quais todos os outros direitos eram subordinados..$^{55}$

Se as revoluções tivessem apenas o objetivo de assegurar os direitos civis, não necessariamente a liberdade teria sido uma consequência. Arendt utiliza 
dois significados da palavra liberdade em inglês para frisar as diferenças: liberty e freedom. Liberty seria liberdade que se segue à libertação, uma liberdade negativa, definida pelas restrições da lei. Freedom seria a liberdade em sentido positivo, derivada da fundação de um espaço público em que o seu exercício ativo significa participação no mundo da política. Os direitos civis, garantido pela liberty, não são positivos no sentido de que não conferem poder aos indivíduos, mas simplesmente garantem a proteção contra os abusos do poder do Estado. Arendt é ainda mais contundente quando afirma que a libertação poderia ser alcançada em um regime monárquico, embora nunca sob a tirania ou o despotismo. Contudo, a liberdade pediria a constituição de uma república. ${ }^{56}$

As revoluções Americana e Francesa introduziram uma novidade na tradição da pólis grega: o espaço da política, reservado para aqueles livres das preocupações com as necessidades básicas da vida, passou a acolher a imensa maioria da população que não era livre, pois estava presa à satisfação das necessidades cotidianas de suas vidas ${ }^{57}$ Assim, para responder a essa questão social, a necessidade se sobrepôs à liberdade como a principal categoria do pensamento político revolucionário. ${ }^{58} \mathrm{~A}$ satisfação das necessidades humanas invadiu o espaço político e os direitos do homem transformaram-se nos direitos civis garantidos pelos Estados-nacionais.

\section{Conclusões: a reconstrução dos direitos humanos, o direito de ter direitos}

A proposta da filosofia política de Hannah Arendt para a reconstrução dos direitos humanos apoia-se no reconhecimento do direito a ter direitos. Ela vai buscar na moral universalista e cosmopolita kantiana o fundamento para se construir um espaço público internacional, em que a política e o direito se efetivem além das fronteiras dos Estados nacionais.

O conceito de humanidade assume uma dimensão ontológica e política. Ontológica, no sentido de que o pertencimento à humanidade garante ao indivíduo a possibilidade de carregar consigo o direito a ter direito. Política, na perspectiva de que o direito a ter direitos exigiria uma tutela internacional homologada na perspectiva da humanidade. ${ }^{59}$ Afirma Arendt: "A humanidade, 
que para o século XVIII, na terminologia kantiana, não passava de uma ideia reguladora, tornou-se hoje de fato inelutável. Esta nova situação, na qual a humanidade assumiu antes um papel atribuído à natureza, ou à história, significaria nesse contexto que o direito a ter direito, ou o direito de cada indivíduo pertencer à humanidade, deveria ser garantido pela própria humanidade". ${ }^{60}$

Para Kant o direito do estrangeiro a não ser tratado com hostilidade não é uma questão de filantropia, mas de direito e hospitalidade. ${ }^{61}$ Para ele, o direito à liberdade, que é originário, tem como consequência o direito sobre o solo. A convivência entre as pessoas de diferentes Estados, não só econômica, mas, no sentido amplo, uma "frequentação mútua e até amistosa", está fundamentado no direito à hospitalidade universal. ${ }^{62}$

Entretanto, segundo Kant, a passagem do "direito de visita" a um "direito de residência" depende de um contrato entre os que chegam e o país de destino. Não é automático, mas é um complemento necessário do "direito dos povos", que deve ser garantido em todos os lugares da terra. ${ }^{63}$ Diz Kant: "A violação dos direitos em um só lugar da terra é sentida em todos os outros". ${ }^{64}$

A referência da análise kantiana é o cidadão, cujo estatuto moral garante a adesão às normas do contrato em outro país e é precondição para o direito à hospitalidade. Pertencer à humanidade, portanto, passa, em primeiro lugar, pela condição de cidadão em seu próprio país e pela adesão às normas de cidadania no país de destino. A ampliação do conceito de cidadania além das fronteiras nacionais não se sobrepõe ao estatuto legal em cada um dos Estados. O pertencer à humanidade possibilita, do ponto de vista moral, como decorrência do direito ao solo e à liberdade, transitar de um país a outro levando consigo seus direitos de cidadão devidamente adequados à legalidade de cada país.

A leitura de Arendt da moral cosmopolita kantiana e de suas consequências políticas deve ser realizada com cautela. Se, para ela, a natureza não concede direitos, o mero pertencimento à humanidade também não poderia conceder. A dimensão ontológica da humanidade deve ser compreendida articulada à sua dimensão política. Ou seja, implica a construção de um espaço político, um artifício, além das fronteiras nacionais, em que as condições de isonomia e pluralidade possibilitam que cada indivíduo seja livre para ter direito a ter direitos. 
Não se trata de uma nova metafísica em que o ser humano, o pertencer à humanidade, substitua a natureza humana como fundamento do direito. Ao contrário, é a existência de um espaço político internacional que garante a dimensão ontológica da humanidade para que ela possa fundar o direito. A humanidade não é nem o resultado final da história, como em Kant, nem a manifestação do espírito absoluto, como em Hegel, mas o resultado da ação humana.

Um espaço político internacional não significa a ilusão totalitária de um Estado internacional subordinando as diferentes nações. Pelo contrário, é um artifício que garante a tutela dos direitos humanos independente dos Estados nacionais, onde a "humanitas" do homem possa se desvelar como mero resultado da natalidade. ${ }^{65}$

A barbárie totalitária que rompeu radicalmente com a tradição dos direitos humanos, chegando aos campos de concentração e de trabalho, exigia das nações uma resposta sem a qual o próprio conceito de humanidade estaria fortemente comprometido. A criação da Organização das Nações Unidas, em 1945, com o objetivo de se constituir em um organismo internacional sem as limitações da Liga das Nações, que teve sua origem em 1919, foi uma resposta para impedir o ressurgimento de um novo desastre humanitário. A sua estrutura, entretanto, era o espelho do mundo que emergia depois da Guerra. No Conselho de Segurança, o seu órgão de maior importância estratégica, garantia-se o poder de veto das grandes potências emergentes e vitoriosas, principalmente os Estados Unidos, a União Soviética, a Inglaterra e a França.

O compromisso efetivo com os direitos humanos não estava garantido com a Carta de fundação da ONU em 1945. Todavia, ela criava a Comissão dos Direitos Humanos, que se propôs a elaborar uma declaração. Depois de três anos de debates, em 10 de dezembro de 1948, foi aprovada pela Assembleia Geral a "Declaração Universal dos Direitos Humanos", com o voto de quarenta e oito países, nenhum voto contra e as abstenções dos países do bloco soviético, da Arábia Saudita e da África do Sul. ${ }^{66}$

Em seu preâmbulo, a Declaração explicita "que o reconhecimento da dignidade inerente a todos os membros da família humana e de seus direitos iguais e inalienáveis é o fundamento da liberdade, da justiça e da paz no mundo". Reconhece, também, mirando o passado recente, "que o desrespeito e o desprezo pelos direitos humanos têm resultado em atos bárbaros que ofenderam a consciência da humanidade e que o advento de um mundo em 
que os seres humanos tenham liberdade de viver sem medo e sem privações foi proclamado como a aspiração mais elementar do homem comum". Portanto seria fundamental que "os direitos humanos sejam protegidos pelo estado de direito, para que o homem não seja compelido a recorrer, em última instância, à rebelião contra a tirania e a opressão". ${ }^{67}$

A fé reafirmada nos direitos humanos e o compromisso dos povos das Nações Unidas em respeitá-los, refletindo a complexidade política do mundo pós-guerra, são amenizados nas conclusões do preâmbulo, quando se afirma: "A Assembleia Geral proclama esta Declaração Universal dos Direitos Humanos como um ideal comum a ser alcançado por todos os povos e todas as nações". ${ }^{68}$

Permanecia o mesmo paradoxo, já evidenciado por Arendt, referindo-se às declarações americana e francesa: ainda que com a pretensão à universalidade, a realização efetiva, política, dos direitos humanos dependia da sua incorporação na legislação de cada país. Os direitos humanos continuavam a ser traduzidos como direitos dos cidadãos de uma determinada nação.

Não se quer minimizar a importância política da Declaração e do sistema de tutela dos direitos humanos implementada pela Organização das Nações Unidas. Ela, sem dúvida, estabeleceu um novo patamar para as relações entre a sociedade e o Estado, particularmente para a democracia. Contudo, no que se refere a sua universalidade, ela incorporou o mesmo paradoxo das declarações americana e francesa: os direitos humanos, ainda que universais, dependem para a sua efetivação política da decisão soberana dos Estados nacionais.

No que se refere à mobilidade da população, a Declaração de 1948 afirma em seu art. 13 o direito de ir e vir e o direito à residência dentro das fronteiras de seu país. Não garante a mobilidade no plano internacional; apenas faz referência ao direito de retorno ao país e, quando o caso, ao direito ao exílio. $\mathrm{O}$ maior avanço se refere ao direito à nacionalidade: ninguém pode ser destituído da sua nacionalidade e fica garantido o direito de mudá-la se assim o indivíduo desejar. ${ }^{69}$

O grave problema dos apátridas e, mesmo, de algumas minorias, que estavam destituídos da sua nacionalidade e impedidos de readquirir outra no seu país de destino, em tese, estaria resolvido com a Declaração da ONU. Efetivamente, entretanto, a nacionalidade, do ponto de vista político e jurídico, depende menos do direito dos indivíduos e mais do seu reconhecimento em 
cada Estado nacional. Os indivíduos detêm a titularidade dos seus direitos, mas o seu reconhecimento no plano internacional se subordina à soberania dos países, verdadeiros titulares no direito público internacional e assim considerado pelo sistema de tutela das Nações Unidas.

Cada Estado assegura-se o direito de legitimar e o de controlar, dentro das suas fronteiras, os movimentos populacionais internacionais e a concessão de nacionalidade. Ambos se constituem em fundamentos de sua própria soberania. Desse modo, as decisões internacionais, como a Declaração de 1948, de fato, significam mais um ideal comum a ser alcançado, sem a força política necessária a se sobrepor à soberania de cada Estado.

A ideia de Hannah Arendt de um espaço político internacional que garanta a tutela dos direitos humanos independente dos Estados nacionais não se efetivou mesmo com os progressos após a Segunda Grande Guerra. Contudo, o direito a ter direito assume na filosofia política uma força heurística decisiva para se compreender o mundo contemporâneo. As restrições impostas pela soberania nacional significam, na perspectiva de Arendt, que os direitos humanos se limitaram aos direitos dos cidadãos em seus respectivos países, estabelecendo limites territoriais e políticos para o pleno exercício da liberdade.

O direito a ter direito não é só uma proposição filosófica para fundamentar uma nova concepção dos direitos humanos, mas uma sinalização política de que a humanidade, nas concepções de Kant e Arendt, não comporta os "displaced persons" e todas as formas de geração de homens supérfluos. O direito a ter direito é a negação do totalitarismo, nas suas formas clássicas do nazismo e do stalinismo, e dos seus resíduos, que ainda prevalecem nas democracias liberais contemporâneas, resistentes a uma verdadeira tutela internacional dos direitos humanos. ${ }^{70}$

\section{Referências bibliográficas}

AMIEL, Anne / Hannah Arendt - Política e Acontecimento, Instituto Piaget, 1996 ARENDT, Hannah - As Origens do Totalitarismo, Editora Companhia das Letras, São Paulo, 2004.

ARENDT, Hannah - On Revolution, Penguin Books, 1990.

BIGNOTTO, Newton - As Aventuras da Virtude, Companhia das Letras, 2010. BIRMINGHAM, Peg - Hannah Arendt and Human Rights, Indiana University Press, 2006.

BOBBIO, Norberto - A Era dos Direitos, Editora Campus, São Paulo, 2004. 
CANOVAN, Margaret - "Arendt's Theory of totalitarianism: a reassessment”, In: The Cambridge Companion to Hannah Arendt, 2000.

CASSIRER, Jean - A questão Jean-Jacques Rousseau, Editora UNESP, São Paulo, 1999

DUARTE, André - O pensamento à Sombra da Ruptura, Política e Filosofia em Hannah Arendt, Editora Paz e Terra, São Paulo, 2000.

FELICIO, Carmelita - "O Direito à Hospitalidade (para além) de um Ponto de Vista Cosmopolitico", In: Correia, A. / Nascimento, Mariângela - Hannah Arendt, Entre o Passado e o Futuro, Editora UFJF, Juiz de Fora, 2008

FRATESCHI, Yara - A Física da Política, Editora UNICAMP, Campinas, 2008

HABERMAS, Jurgen - A Inclusão do Outro, Estudos de Teoria Politica, Editora Loyola, São Paulo, 2002.

HOBBES,Thomas - Leviatã, Richard Tuck (org), Editora Martins Fontes, São Paulo, 2003.

HOBBES, Thomas - Do cidadão, Editora Martins Fontes, 2002.

HUNT, Lynn - A Invenção dos Direitos Humanos, uma história, Editora Companhia das Letras, São Paulo, 2009.

KANT, Immanuel - A Paz Perpétua, Guinsburg (org), Editora Perspectiva, São Paulo, 2004.

KAVERGAN, Jean-François - "Os Direitos Humanos", In: Ensaios de Filosofia Política, Editora UNISINOS, São Leopoldo, 2001.

LAFER, Celso - Hannah Arendt, Pensamento, Persuasão e Poder, Paz e Terra, São Paulo, 2003.

LEFORT, Claude - Pensando o Político. Ensaios sobre Democracia, Revolução e Liberdade, Paz e Terra, Rio de Janeiro, 1991.

LOCKE, John - Dois tratados sobre o governo, Editora Martins Fontes, São Paulo, 2005.

ROUSSEAU, Jean-Jacques - O Contrato Social, Editora Martins Fontes, São Paulo, 2003.

SCHIMITT, Carl - Teoria de la Constituición, Alianza Editorial, Madrid, 1982.

SKINNER, Quentin - Hobbes e a Liberdade Republicana, Editora UNESP, 2010. 